\title{
Erythrocyte Sedimentation Rate Measurement
}

National Cancer Institute

\section{Source}

National Cancer Institute. Erythrocyte Sedimentation Rate Measurement. NCI

Thesaurus. Code C74611.

A quantitative measurement of the distance that red blood cells travel in one hour in a sample of unclotted blood. 